\title{
Millennial-Scale Planktic Foraminifer Faunal Variability in the East China Sea during the Past 40000 Years (IMAGES MD012404 from the Okinawa Trough)
}

\author{
Yuan-Pin Chang ${ }^{1}$, Wei-Lung Wang ${ }^{2}$, Yusuke Yokoyama ${ }^{3}$, Hiroyuki Matsuzaki ${ }^{4}$, \\ Hodaka Kawahata ${ }^{5}$, and Min-Te Chen ${ }^{1, *}$ \\ ${ }^{1}$ Institute of Applied Geosciences, National Taiwan Ocean University, Keelung 20224, Taiwan, ROC \\ ${ }^{2}$ Department of Biology, National Changhua University of Education, Changhua, Taiwan, ROC \\ ${ }^{3}$ Department of Earth and Planetary Sciences, University of Tokyo, Tokyo, Japan \\ ${ }^{4}$ Department of Nuclear Engineering and Management, University of Tokyo, Tokyo, Japan \\ ${ }^{5}$ Ocean Research Institute, University of Tokyo, Tokyo, Japan
}

Received 10 June 2006, accepted 21 September 2007

\begin{abstract}
High resolution planktic foraminifer fauna assemblage data are used to reconstruct the millennial-scale sea surface temperature (SST) variability of the past 40000 years at an IMAGES core site (MD012404) in the Okinawa Trough in the East China Sea (ECS). The fauna assemblages in core MD012404 are dominated by five species - Globigerinoides ruber, Globigerina bulloides, Neogloboquadrina dutertrei, Pulleniatina obliquiloculata, and Globigerinita glutinata, which account for $>70 \%$ in relative abundance. Our Q-mode factor analysis decomposed the fauna abundance data into three factors, which indicate cold water mass, warm water mass, and possibly coastal water flow with low salinity in the ECS. The MD012404 fauna data show abrupt changes at $\sim 16$ kya, suggesting a return to a warmer climate or warm water intrusion of the Kuroshio into the Okinawa Trough since the Last Glacial Maximum (LGM). SST estimates based on the fauna assemblages of planktic foraminifers indicate a LGM cooling of $1-2^{\circ} \mathrm{C}$. A maximum cooling by $3-4^{\circ} \mathrm{C}$ is observed in episodic, millennial-scale events in the glacial stages of the record. The SST record displays variability that closely tracks the structure of oxygen isotopes of stalagmites from Hulu Cave and ice cores from GISP 2 Dansgaard/Oeschger cycles and Heinrich events. Low salinity in the ECS is inferred based on MD012404 fauna SST and planktic foraminifer oxygen isotope records for the cold millennial-scale intervals, pointing to the Intertropical Convergence Zone (ITCZ) and/or East Asian monsoon as important factors driving SST and salinity in the subtropical western Pacific, both on orbital and suborbital time scales.
\end{abstract}

Key words: Planktic foraminifer, Sea surface temperature, ITCZ, East China Sea, Okinawa Trough, IMAGES

Citation: Chang, Y. P., W. L. Wang, Y. Yokoyama, H. Matsuzaki, H. Kawahata, and M. T. Chen, 2008: Millennial-scale planktic foraminifer faunal variability in the East China Sea during the past 40000 years (IMAGES MD012404 from the Okinawa Trough). Terr. Atmos. Ocean. Sci., 19, 389-401, doi: 10.3319/TAO.2008.19.4.389(IMAGES)

\section{INTRODUCTION}

The East China Sea (ECS) is one of the marginal seas of the western Pacific, located between the Japan Sea and the South China Sea and connected to Asia with wide continental shelves. The Okinawa Trough is a back-arc spreading basin in the southeastern part of the ECS. The surface hydrography in the ECS near the Okinawa Trough is governed by the Kuroshio, a main western boundary current in the northwestern Pacific. The Kuroshio waters are warm

* Corresponding author

E-mail: mtchen@mail.ntou.edu.tw $\left(>20^{\circ} \mathrm{C}\right)$ and have relatively high salinities $(\geq 34 \mathrm{psu})$, flowing along the western edge of North Pacific subtropical mode water (NPSTMW). The Kuroshio is responsible for great heat and moisture transport from the tropics to the middle latitudes (Hsueh 2000; Ichikawa and Chaen 2000). The mean seasonal range of surface heat transports in the Okinawa Trough is $\sim 300 \mathrm{E} \mathrm{m}^{-2}$ (Qiu et al. 2004).

Playing an important role in the global climate system, the Kuroshio also has a strong impact on regional surface hydrography in the western Pacific near East Asia. Under the control of the complicated bathymetry of the western Pa- 
cific basins, the Kuroshio enters the ECS along the eastern side of Taiwan and intrudes into the Okinawa Trough along the ECS's continental shelves (Fig. 1). The seasonal SST and salinity of the ECS near the Okinawa Trough are also controlled by East Asian monsoons. The observed mean annual SST is $\sim 24.7^{\circ} \mathrm{C}$, with a seasonal range between $\sim 28.6^{\circ} \mathrm{C}$ (July) and $\sim 21.8^{\circ} \mathrm{C}$ (January). Mean annual sea surface salinity is $\sim 34.4 \mathrm{psu}$, with a summer low of $\sim 34.1 \mathrm{psu}$ and a winter high of $\sim 34.7$ psu [National Oceanic and Atmospheric Administration (NOAA) 1994]. The seasonal salinity variability in the ECS is largely influenced by fresh water input from the Yangtze River (Changjiang). During the summer, strong summer monsoons (southwesterly) and the relatively northward Intertropical Convergence Zone (ITCZ) bring high precipitation into southern China, the drainage area of the Yangtze River, which in turn leads to a great volume of fresh water discharge that reduces surface salinity in the ECS. The relatively low summer salinity observed in the ECS indicates dominant monsoon and/or ITCZ effects relative to the intrusion process of the Kuroshio, which is transporting more saline water from the Pacific in the summer.

Previous work using planktic foraminifer fauna-based hydrographic records from the Okinawa Trough has suggested that the Kuroshio intrusion flow was blocked by the land bridge of the Ryukyu Arc during lower sea level glacial conditions (Ujiié et al. 1991; Ahagon et al. 1993; Ujiié and Ujiié 1999). It has been assumed that the Kuroshio did not penetrate into the Okinawa Trough during the glacial period from 16 to $45 \mathrm{kya}$ ( $\mathrm{Li}$ et al. 2001). The weak strength of the North Equator Current where the Kuroshio originates, with an ENSO-like climatic condition in the equatorial Pacific, may have led to the eastward migration of the Kuroshio during the Pulleniatina Minimum Event (PME) 3.5 kya (Ujiié et al. 2003). This interpretation is consistent with modern hydrographic observations that the Kuroshio is weakened during El Niño years and strengthened in La Niña years (Kim et al. 2004). Other ECS sediment core studies (Jian et al. 1996, 2000b; Li et al. 1997) also have proposed the same scenario - that the Kuroshio was weak and/or shifted toward the Pacific during the PME in $\sim 2$ to 5 kya of the late Holocene. But a reconstructed $\mathrm{Mg} / \mathrm{CaSST}$ record had shown that the SST did not have a declining trend during this period (Lin et al. 2006), and the author concluded that PME might have resulted from a decrease or migrating of the Kuroshio. All evidence from previous works has suggested short-term, millennial-scale variability in surface hydrography in the ECS during the late Quaternary.

Large surface ocean cooling has been inferred in the ECS during the Last Glacial Maximum (LGM) and the Younger Dryas (YD) using transfer function-type planktic foraminifer SST estimates and evidence of low abundances of the Kuroshio indicator species Pulleniatina obliquiloculata (Li et al. 1997; Liu et al. 1999; Li et al. 2001). These

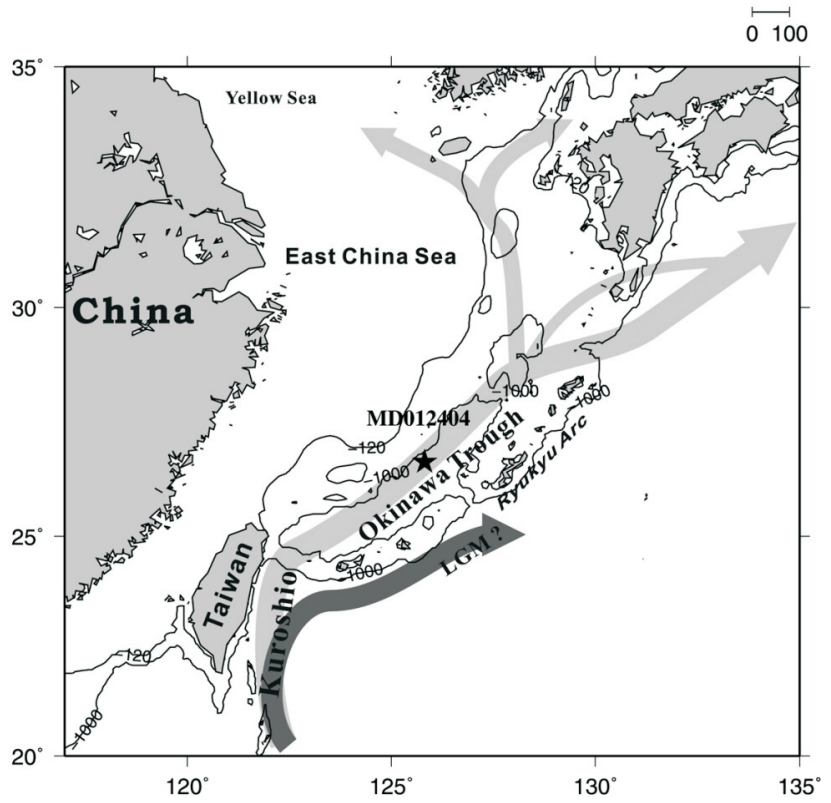

Fig. 1. Physiographic map showing the location of core MD012404. The modern flowing path of the Kuroshio is indicated by a gray line and the possible change of the Kuroshio main stream in LGM is shown as a dark line with a question mark.

previous studies also reported a similar magnitude of cooling in surface ECS waters during the past four Heinrich events (H1 to $\mathrm{H} 4)$ that were observed in the high-latitude North Atlantic and globally (Bond et al. 1992; Hemming 2004). Large-scale shifting or absence of the Kuroshio in the Okinawa Trough in response to intensified East Asian winter monsoons and/or coastal cold water from the north was called upon to explain large SST or fauna variability. A later study using planktic foraminifer fauna and pollen assemblages suggested, however, that the Kuroshio existed in the Okinawa Trough throughout the last glacial stage (Kawahata and Ohshima 2004). More recently, a short 20-kyr long record from the Okinawa Trough using planktic oxygen isotope and $\mathrm{Mg} / \mathrm{Ca} \mathrm{SST}$ has indicated a warming trend with increased salinity since the last deglaciation in the ECS (Sun et al. 2005). This glacial to interglacial transition of surface hydrography echoes the increased strength of the East Asian summer monsoon since the early Holocene that has been proposed by most previous monsoon studies. Superimposed on the long-term trend, this study suggests that the millennial-scale variability in the ECS is characterized by a series of warm/saline, and cold/fresh conditions, which need other mechanisms to account for the millennial-scale variability. Despite possibly complicated mechanisms, all of these cases indicate a need for long-term, and high-resolution records for better reconstruction of SST and salinity in order to identify all possible factors and linkages governing climate variability in the ECS.

In the current study, high-resolution planktic foraminifer fauna abundance data and SST estimates were generated 
from core MD9012404, which was collected in the middle part of the Okinawa Trough from a WEPAMA cruise of the IMAGES (International Marine Global Changes Study) program in 2001 (Bassinot et al. 2002). Specific objectives of this study are to: (1) document the high-resolution, millennial-scale variations of planktic foraminifer fauna assemblages of the past 40000 years in core MD012404; (2) estimate SST variations based on the planktic foraminifer fauna record using the Revised Analog Method (RAM) (Waelbroeck et al. 1998); (3) estimate the SST changes in the ECS; and (4) identify the linkage between the ECS SST record and a stalagmite monsoon record from Hulu Cave (Wang et al. 2001), and a GISP ice core record from the high latitudes of the Northern Hemisphere (Grootes and Stuiver 1997).

\section{MATERIALS AND METHODS}

\subsection{Core Descriptions and Age Models}

The IMAGES core MD012404 used in this study was taken at $26^{\circ} 38.84^{\prime} \mathrm{N}, 125^{\circ} 48.75^{\prime} \mathrm{E}$ in the middle part of the Okinawa Trough at a water depth of $1397 \mathrm{~m}$, which is well above the carbonate lysocline $(\sim 3000 \mathrm{~m})$ of the western Pacific (Thunell et al. 1992) (Fig. 1). The total length of core MD012404 is $43.67 \mathrm{~m}$. The sediment compositions of the core are silty clays dominated by nannofossil ooze with diatoms and foraminifers. The color of the sediment core changes from grayish olive green to olive gray with dark organic-rich layers and spots (Bassinot et al. 2002). No visible layers of volcanic ash are found in the sediments; pyrites or volcanic glasses are found at some intervals of the core. The sediments were sliced into $1-\mathrm{cm}$ thick samples on board and were kept in a refrigerator under $4^{\circ} \mathrm{C}$ before processing. Sub-samples of approximately $10 \mathrm{~g}$ were taken from the slice samples at 5-cm depth intervals for the purpose of this study in order to conduct planktic foraminifer assemblage analysis. All laboratory procedures were done in the Laboratory of Earth, Environment and Climate Variability, Institute of Applied Geosciences at the National Taiwan Ocean University.

The age model of core MD012404 was established using planktic foraminifer AMS ${ }^{14} \mathrm{C}$ dating. We added 14 new AMS ${ }^{14} \mathrm{C}$ datings to those presented in Chang et al. (2005) in the age control of the record of the past 40000 years (Table 1). The AMS ${ }^{14} \mathrm{C}$ measurements were done by taking $\sim 20 \mathrm{mg}$ of planktic foraminifers G. ruber and G. sacculifer $(>250 \mu \mathrm{m})$ shells and dating them at the Micro Analysis Laboratory's Tandem Accelerator (MALT) at The University of Tokyo. All AMS ${ }^{14} \mathrm{C}$ ages were adjusted for a mean Pacific reservoir age of 400 years. All ages younger than 21000 years BP

Table 1. AMS ${ }^{14} \mathrm{C}$ age control points used to age the model of core MD012404. Reservoir age of 400 years was subtracted from the ${ }^{14} \mathrm{C}$ ages before calibration. A CALIB 5 program and Bard's (2004) equation were used in the calibration.

\begin{tabular}{|c|c|c|c|c|c|}
\hline Depth (cm) & AMS ${ }^{14} \mathrm{C}$ Age & & Error $^{a}$ & Calendar Age (year) & Species \\
\hline 14.5 & 1040 & \pm & 70 & 749 & G.sacculifer \\
\hline 104.5 & 2350 & \pm & 30 & 2150 & G.sacculifer + G.ruber \\
\hline 254.5 & 4500 & \pm & 110 & 4875 & Gssacculifer \\
\hline 349.5 & 6450 & \pm & 30 & 7093 & G.sacculifer + G.ruber \\
\hline 494.5 & 9730 & \pm & 120 & 10818 & G.sacculifer \\
\hline 589.5 & 10820 & \pm & 190 & 12366 & G.sacculifer \\
\hline 624.5 & 11370 & \pm & 40 & 13093 & G.sacculifer + G.ruber \\
\hline 744.5 & 12680 & \pm & 130 & 14686 & G.sacculifer \\
\hline 854.5 & 13950 & \pm & 90 & 16299 & G.sacculifer \\
\hline 904.5 & 14560 & \pm & 45 & 17058 & G.sacculifer + G.ruber \\
\hline 1019.5 & 15810 & \pm & 160 & 18822 & G.sacculifer \\
\hline 1194.5 & 19520 & \pm & 230 & 22975 & G.sacculifer \\
\hline 1379.5 & 21360 & \pm & 70 & 25307 & G.sacculifer + G.ruber \\
\hline 1454.5 & 23230 & \pm & 270 & 26757 & G.sacculifer \\
\hline 1539.5 & 24450 & \pm & 490 & 28122 & G.sacculifer \\
\hline 1719.5 & 27970 & \pm & 200 & 32019 & G.sacculifer + G.ruber \\
\hline 1814.5 & 30200 & \pm & 230 & 34456 & G.sacculifer + G.ruber \\
\hline 2074.5 & 32490 & \pm & 1110 & 36932 & G.sacculifer + G.ruber \\
\hline 2174.5 & 34010 & \pm & 280 & 38561 & G.sacculifer + Gruber \\
\hline
\end{tabular}

a. Error is gave in $1 \sigma$ 
were calibrated into calendar years by using CALIB program 5.0 (Stuiver et al. 2005), and those older than 21000 years BP were calibrated using the equation found in Bard et al. (2004). With this age model, the mean sedimentation rate was estimated to be approximately $50 \mathrm{~cm} \mathrm{kyr}^{-1}$ in the record of MD012404 during the past 40000 years (Fig. 2h), and it is able to resolve millennial-scale variability in the past ECS climate.

Oxygen isotopes of the planktic foraminifer G. ruber (white) sensu stricto (s.s.) were also measured for core MD012404 in order to resolve the hydrographic history of the ECS during the past 40000 years. The oxygen isotope analyses were done using a Micromass IsoPrime isotope ratio mass spectrometer housed in the Geological Survey of Japan, National Institute of Advanced Industrial Science and Technology (AIST) at Tsukuba, Japan. The NBS-19 was used as the carbonate standard for calibrating the G. ruber shell samples to the PeeDee Belemnite (PDB).

Volcano glass abundance layers were observed at core depths of 354 and $1559 \mathrm{~cm}$. These layers are dated as 7.3 and 28.5 kya, and coincide with major eruption events re- corded in the northern volcanoes of Kikai and Aira on Kyushu Island, Japan (Machida and Arai 1976; Machida and Arai 1978; Machida 1999; Machida 2002).

\subsection{Planktic Foraminifer Fauna Assemblages}

High-resolution planktic foraminifer faunal abundance data were generated from core MD012404 in this study. Samples from every $5-\mathrm{cm}$ interval from the top $15 \mathrm{~m}$ and from every $10-\mathrm{cm}$ interval from 15 - to 21 -m depths, a total of 366 samples, were used for the fauna analyses. All samples were freeze-dried and weighed, and then washed through a $104-\mu \mathrm{m}$ sieve under a weak spray of water. After drying the washed samples in a $50^{\circ} \mathrm{C}$ oven overnight, the samples were again sieved through a $>149 \mu \mathrm{m}$ size fraction and split into sub-samples which contained $>300$ whole specimens for identifying and counting under a microscope. The taxonomy of planktic foraminifers adopted in this study followed the scheme used in compiling a new western Pacific coretop database (Chen et al. 2005), in which Globorotalia menardii and Globorotalia tumida were combined into one species,

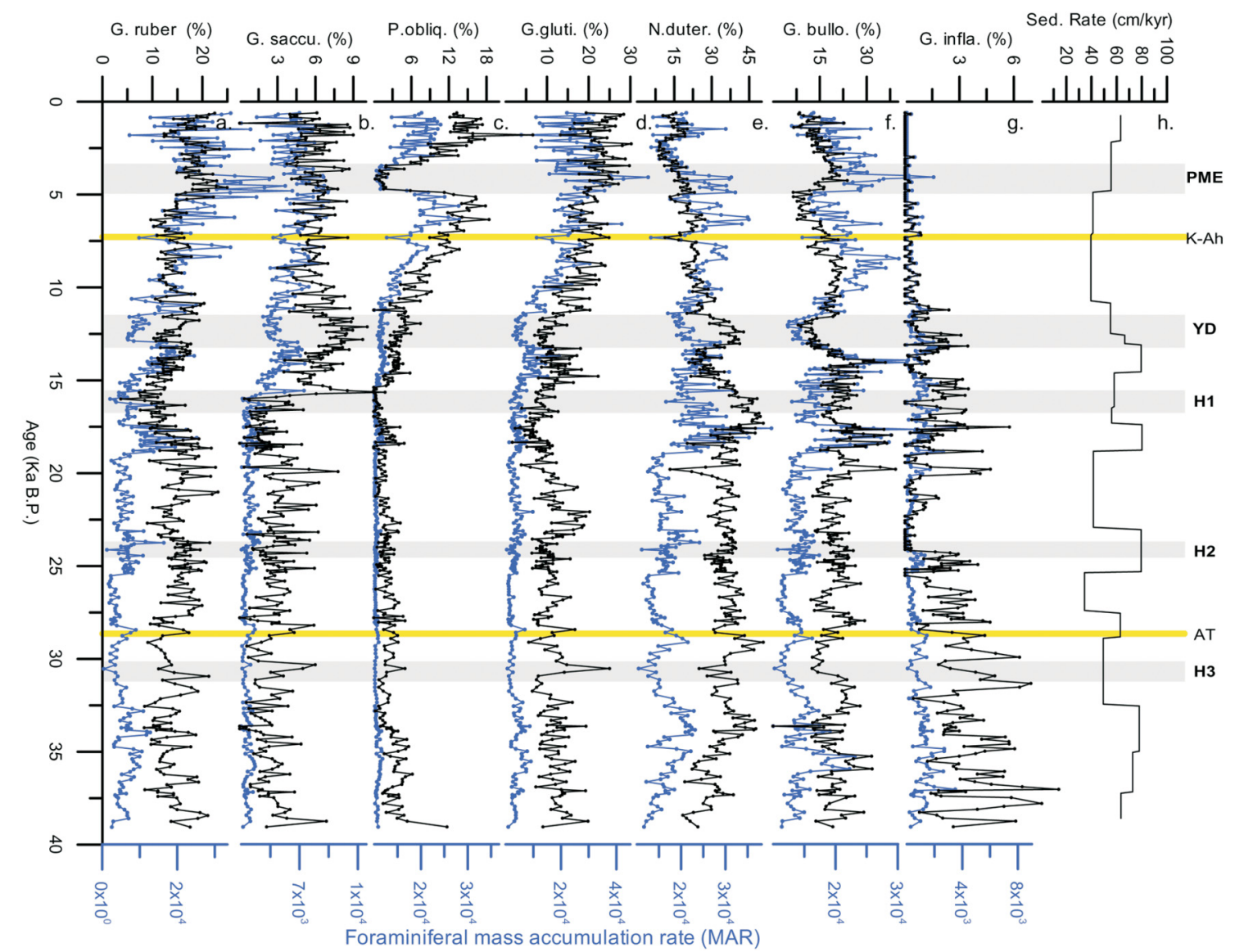

Fig. 2. Downcore variations in planktonic foraminiferal assemblages and the mass accumulation rate (MAR) are represented by a gray line. (a) $G$. ruber, (b) G. sacculifer, (c) P. obliquiloculata, (d) G. glutinata, (e) N. dutertrei, (f) G. bulloides, (g) G. inflate, (h) sedimentation rate. Triangles indicate the calibrated ${ }^{14} \mathrm{C}$ age used to reconstruct the age model in this study. Shadow areas mark the Heinrich events with a number and the Younger Dryas is denoted by YD in the above. Two volcanic eruption events at 7.3 and $28.5 \mathrm{ka} \mathrm{BP}$ are marked with a gray bar, which denotes K-Ah and AT, respectively. 
G. menardii, and Neogloboquadrina dutertrei and Neogloboquadrina pachiderma (dextral) also were lumped into one unit, $N$. dutertrei. All fauna counting data are presented in relative abundances of species and also in absolute abundances (the total number of foraminifer shells per gram of sediment). A Q-mode factor analysis was applied by using the CABFAC program (Imbrie and Kipp 1971; Klovan and Imbrie 1971) to reduce the fauna abundance data into a few independent factors for interpreting water mass or hydrographic variations in the downcore records.

We calculated the mass accumulation rate [MAR, $\left.\left(\# \mathrm{n} \mathrm{cm}^{-2}\right) \mathrm{kyr}^{-1}\right]$ of foraminifers by using a procedure suggested in (Sykes and Ramsay 1995). On-board gamma ray density data were used as wet bulk density (WBD) (Bassinot et al. 2002). Porosity data were calculated following Simmons (1990):

$\mathrm{MAR}=\mathrm{F} \times[\mathrm{WBD}-(\mathrm{P} \times \mathrm{WD})] \times \mathrm{SR}$

where $\mathrm{F}$ is the total number of foraminifers $\left(\# \mathrm{n}^{-1}\right)$, WBD is wet bulk density $\left(\mathrm{g} \mathrm{cm}^{-3}\right), \mathrm{P}$ is porosity $(\mathrm{P}=0.72$ $0.045 \mathrm{Z}, \mathrm{Z}=$ core depth in $\mathrm{km}$ ) (Simmons 1990), and WD is the density of seawater $\left(1.03 \mathrm{~g} \mathrm{~cm}^{-3}\right)$ (Beicher 2000).

\subsection{RAM SST Estimates}

The Revised Analog Method (RAM) (Waelbroeck et al. 1998) was used in this study for estimating MD012404 SST variation during the past $40 \mathrm{kya}$. The RAM was proposed to improve the accuracy and precision of SST estimations based on planktic foraminifer fossil faunas. The RAM uses a dissimilarity coefficient (squared chord distance) to measure the dissimilarity between the fauna abundance data of coretop and downcore samples. Higher values of the squared chord distance indicate less similar samples. The squared chord distance also has the effect of amplifying the signals of less dominant species abundances. This method was considered valid with a precision of $\leq 1{ }^{\circ} \mathrm{C}$ in testing against a western Pacific coretop database (Chen et al. 2005). We used a threshold value of the dissimilarity coefficient of 0.6 with the RAM and reported summer, winter, and annual average SSTs from the fauna record of core MD012404.

\section{RESULTS AND DISCUSSION}

At the MD012404 core site of the Okinawa Trough in the ECS, fauna analyses of planktic foraminifers reveal that out of a total 27 identified species, there are seven dominant species with abundances $\geq 3 \%$ (Table 2 ). The most abundant species, $N$. dutertrei, constitutes $\sim 50 \%$ at its maximum and also a gradually decreasing pattern from 40 kya to the Holocene (Fig. 2e). The abundances of $N$. dutertrei are high in glacial stages MIS (Marine Isotope Stage) 2 to MIS 3, and appear to be an indicator of cold water mass in the ECS
(Fig. 2e). Globigerina bulloides is the second dominant species, reaching $\sim 40 \%$ at its maximum, and relatively high abundances but more high-frequency oscillations during glacial stages (Fig. 2f). In the surface sediments, G. bulloides abundances are relatively higher on ECS continental shelves, indicating cold coastal waters (Xu and Oda 1999). The abundances of the tropical and sub-tropical species $G$. ruber (15\% on average) (Fig. 2a), G. sacculifer ( $4 \%$ on average) (Fig. 2b), Globigerinita glutinata (14\% on average) (Fig. 2d), and P. obliquiloculata (4\% on average) (Fig. 2c) all display gradually increasing trends from the LGM to the Holocene, suggesting a return back to warm water mass conditions in the ECS after the glacial periods or a reentering of the Kuroshio into the Okinawa Trough from the Pacific. Previous studies suggest that these warm water species are associated with the main path of the Kuroshio (Oda and Takemoto 1992; Ujiié and Ujiié 1999; Xu and Oda 1999). A PME-type event with minimum $P$. obliquiloculata abundances is also observed in the MD012404 record of $\sim 3$ to 5 kya (Ujiié et al. 1991; Li et al. 1997; Ujiié and Ujiié 1999; Ujiié et al. 2003) (Fig. 2c).

Two deep-dwelling species, Globolotalia inflata (Fig. 2g) and Globolotalia truncatulinoides (left + right coiling morphotypes) (Fig. 3), display temporal variations that might be linked to deep thermoclines and/or thick mode water thermostads in the ECS. G. inflata is an indicator for transitional and subpolar water, preferring to live at the bottom of thermocline depths (Bé 1977; Hemleben et al. 1989). High abundances of $G$. inflata indicate conditions of weakly stratified water columns with strong coastal upwelling, e.g., the Peru Current in the southeastern Pacific (Feldberg and Mix 2002). In MD012404, G. inflata appears in relatively high abundance in the glacial stages but increases abruptly in short episodes of the record. G. truncatulinoides is also indicative of deep mixing conditions in the upper layer of surface oceans as well as the thickness of the NPSTMW thermostads (Jian et al. 2000a). The occurrence of G. truncatulinoides in glacial stages (Fig. 3a) is therefore used to infer a strongly mixing, more weakly stratified layer of upper ocean conditions in the ECS during the glacial periods.

The MAR of all planktic foraminifers reveals a gradually increasing trend from 35 kya to the Holocene, and an abruptly increasing one since $16 \mathrm{kya}$ (Fig. $3 \mathrm{~d}$ ). We also found a similar trend of gradual increase in the MAR of warm planktic foraminifer species that include G. ruber, G. glutinata, and P. obliquiloculata since $\sim 16$ kya (Fig $3 b$ ). This trend has been assumed to indicate the intrusion of the Kuroshio into the Okinawa Trough (Ujiié and Ujiié 1999; Ujiié et al. 2003; Kao et al. 2005, 2006). The change of the foraminifer MARs coincides with the variations of carbonate contents in MD012404 (Fig. 3d), suggesting that the carbonate contents are driven by foraminifer productivity and/or carbonate preservation in the Okinawa 
Table 2. Statistic of 27 planktic foraminifer species abundance data from 364 downcore samples of core MD012404

\begin{tabular}{|c|c|c|c|c|}
\hline Foraminifera species & Average (\%) & St. Dev. (\%) & Minimum (\%) & Maximum (\%) \\
\hline Orbulina universa & 0.87 & 0.69 & 0.00 & 4.24 \\
\hline Globigerinoides conglobatus & 0.34 & 0.47 & 0.00 & 2.30 \\
\hline Globigerinoides ruber & 14.85 & 3.47 & 3.68 & 24.94 \\
\hline Globoturborotalita tenellus & 1.38 & 0.81 & 0.00 & 4.67 \\
\hline Globigerinoides sacculifer & 4.34 & 2.38 & 0.00 & 11.52 \\
\hline Sphaeroidinella dehiscens & 0.04 & 0.13 & 0.00 & 1.08 \\
\hline Globigerinella aequilateralis & 1.12 & 0.68 & 0.00 & 3.74 \\
\hline Globigerinella calida & 3.35 & 1.76 & 0.00 & 13.97 \\
\hline Globigerina bulloides & 18.68 & 5.64 & 0.00 & 39.22 \\
\hline Globigerina falconensis & 0.73 & 0.75 & 0.00 & 4.10 \\
\hline Beela digitata & 0.10 & 0.19 & 0.00 & 1.03 \\
\hline Globoturborotalita rubescens & 1.40 & 0.83 & 0.00 & 4.59 \\
\hline Turborotalita humilis & 0.01 & 0.07 & 0.00 & 0.61 \\
\hline Globigerina quinqueloba & 0.64 & 0.89 & 0.00 & 6.67 \\
\hline Neogloboquadrina pachyderma (L) & 0.10 & 0.23 & 0.00 & 1.22 \\
\hline Neogloboquadrina dutertrei* & 30.54 & 9.87 & 8.78 & 50.66 \\
\hline Globoquadrina conglomerata & 0.50 & 0.72 & 0.00 & 3.77 \\
\hline Pulleniatina obliquiloculata & 4.54 & 4.67 & 0.00 & 25.39 \\
\hline Globotalia inflata & 1.28 & 1.45 & 0.00 & 6.95 \\
\hline Globotalia truncatulinoides $(\mathrm{L})$ & 0.02 & 0.11 & 0.00 & 1.39 \\
\hline Globotalia truncatulinoides $(\mathrm{R})$ & 0.43 & 0.47 & 0.00 & 2.60 \\
\hline Globotalia crassaformis & 0.09 & 0.20 & 0.00 & 1.50 \\
\hline Globotalia hirsuta & 0.07 & 0.18 & 0.00 & 1.48 \\
\hline Globotalia scitula & 0.33 & 0.44 & 0.00 & 2.34 \\
\hline Globotalia menardii & 0.65 & 0.64 & 0.00 & 2.93 \\
\hline Globotalia tumida & 0.01 & 0.06 & 0.00 & 0.90 \\
\hline Globigerinita glutinata & 13.59 & 5.87 & 1.68 & 30.19 \\
\hline
\end{tabular}

* N. dutertrei includes $N$. dutertrei and N. pachyderma $(\boldsymbol{R})$.

Trough. Our foraminifer fragmentation index [WPF: whole planktic foraminifer / (WPF + Fragments)] indicates good preservation in the glacial and more dissolution in the interglacial periods in the MD012404 record (Fig. 3c), ruling out the possibility that the carbonate contents are driven by preservation changes. The glacial low carbonate contents in MD012404 appear to reflect the dilution effect of increased terrestrial, relative to carbonate, sediments in the Okinawa Trough during low sea level conditions. The dilution effects of volcanic glasses are also clearly observed in the relatively low carbonate content and MAR of the record at 7.3 and 28.5 kya that are labeled $\mathrm{K}-\mathrm{Ah}$ and AT, respectively (Fig. 3d).

Our Q-mode factor analysis of the relative abundance data of the 27 planktic foraminifer species assemblage in core MD012404 (Table 3) indicates that three factors account for $>97 \%$ of the total variance of the data (Table 3 ).
The first factor explains $58 \%$ of the total variance and is entirely dominated by $N$. dutertrei $(N$. dutertrei $+N$. pachyderma dex.). Factor 1 loadings show high abundances in glacial stages but exhibit a decreasing trend since $\sim 16$ kya (Fig. 4a). Higher values of the factor 1 loadings are found in the Heinrich, YD, and PME intervals (Fig. 4a). Factor 2 explains $36 \%$ of the total variance and is correlated with the abundances of warm water mass assemblages G. ruber, $G$. glutinata, and P. obliquiloculata (Table 3). Factor 2 loadings are relatively low in glacial stages but increase gradually from $\sim 16$ kya (Fig. 4b). Low factor 2 loadings are observed in Heinrich, YD, and PME events. Factor 3 only explains $4 \%$ of the total variances and is dominated by one species, $G$. bulloides (Table 3 ). This species generally indicates nutrient-rich upwelling conditions (Bé 1977), and is abundant in the continental shelf of the ECS and the edge of the Kuroshio (Ujiié and Ujiié 1999; Xu and Oda 1999). The variations of 


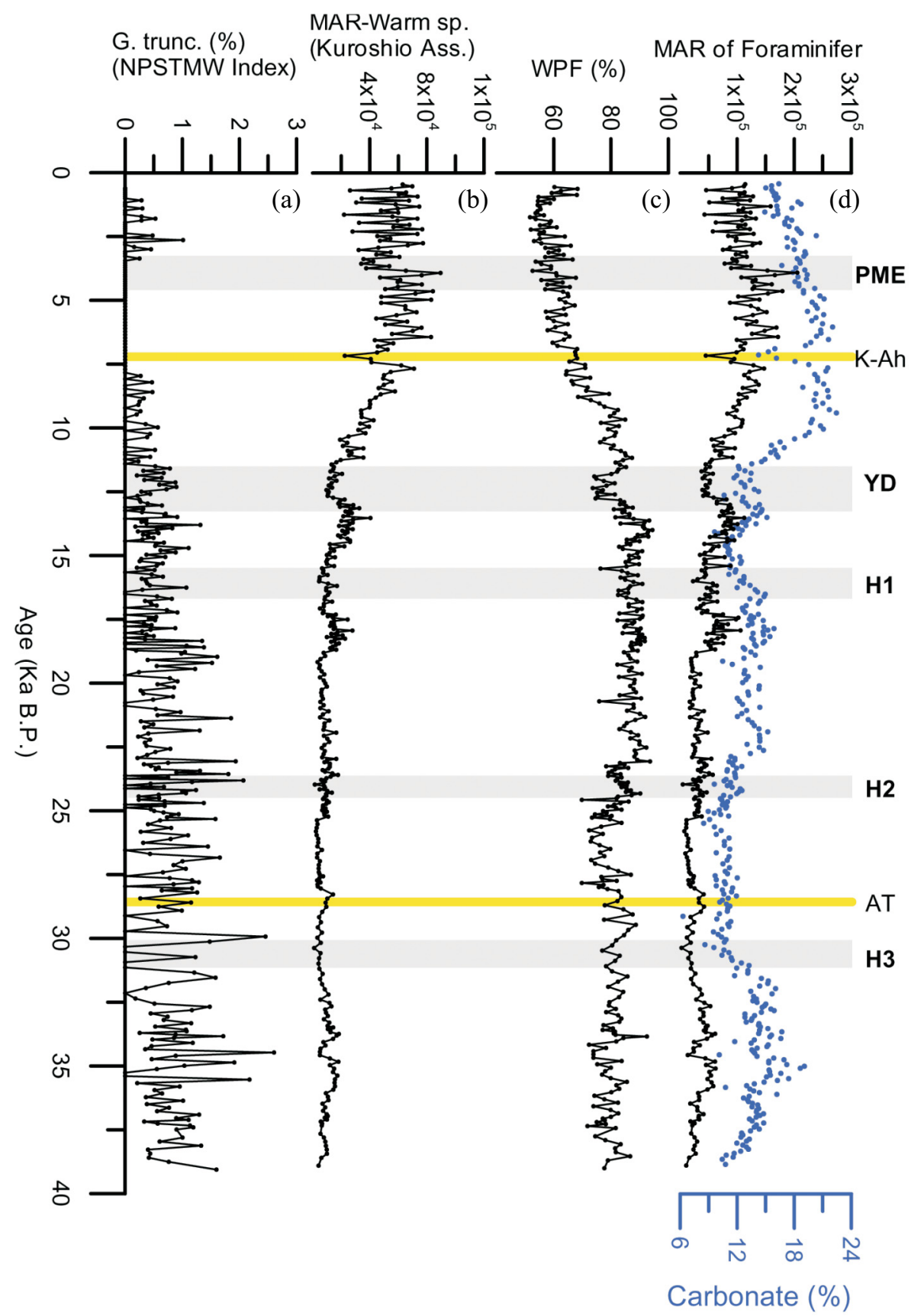

Fig. 3. (a) Percentage data of G. truncatulinoides were compiled with dextral and sinistral individuals which can be seen in the NPSTMW index in the North Pacific. (b) MAR data of warm species that combined with G. ruber, G. glutinata, and P. obliquiloculata to give the Kuroshio index in this study. (c) The preservation index which reveals the dissolution effect in this region. (d) MAR data that was calculated with all foraminiferal species and can serve as an index of carbonate productivity; gray dots represent the measured carbonate data.

factor 3 loadings display high-frequency oscillations without obvious correlations with millennial-scale climatic events (Fig. 4c). We speculate that this third factor could be an indicator of local mixing processes associated with high nutrient levels and/or riverine input between the zone of the continental shelf and the edge of the Kuroshio in the ECS (Ijiri et al. 2005).

A high-resolution MD012404 SST record was produced by applying a RAM based on the planktic foraminifer fauna abundance data (Fig. 5b). Summer, winter, and annual average SSTs were reconstructed to reveal the sea surface water condition changes in the Okinawa Trough of the ECS. The dissimilarity coefficients between coretop and downcore samples range from 0.04 to 0.38 , with a mean value of 0.15 , indicating that good analogues were used to calculate the RAM SSTs (Fig. 5a). The glacial downcore samples have higher dissimilarities (Fig. 5a). Possible explanations for these higher dissimilarities might be less good analogues in 
Table 3. Q-mode factor analysis of MD012404 fauna abundance data. Major factor scores are marked in bold and underline. Three factors explain $98 \%$ of the total variance.

\begin{tabular}{lccc}
\hline \multicolumn{1}{c}{ Foraminifera species } & F1 & F2 & F3 \\
\hline Orbulina universa & 0.021 & 0.012 & -0.013 \\
Globigerinoides conglobatus & -0.011 & 0.030 & 0.001 \\
Globigerinoides ruber & 0.096 & $\mathbf{0 . 4 4 7}$ & 0.073 \\
Globoturborotalita tenellus & 0.011 & 0.043 & -0.003 \\
Globigerinoides sacculifer & 0.000 & 0.192 & -0.020 \\
Sphaeroidinella dehiscens & -0.001 & 0.004 & -0.004 \\
Globigerinella aequilateralis & 0.009 & 0.036 & -0.004 \\
Globigerinella calida & 0.025 & 0.110 & 0.002 \\
Globigerina bulloides & 0.223 & 0.185 & $\mathbf{0 . 9 3 4}$ \\
Globigerina falconensis & -0.001 & 0.032 & -0.010 \\
Beela digitata & 0.002 & 0.003 & -0.003 \\
Globoturborotalita rubescens & 0.021 & 0.020 & 0.028 \\
Turborotalita humilis & -0.001 & 0.001 & -0.000 \\
Globigerina quinqueloba & 0.025 & -0.007 & 0.001 \\
Neogloboquadrina pachyderma (L) & 0.004 & -0.001 & -0.002 \\
Neogloboquadrina dutertrei* & $\underline{\mathbf{0 . 9 5 4}}$ & 0.039 & -0.262 \\
Globoquadrina conglomerata & -0.015 & 0.045 & -0.017 \\
Pulleniatina obliquiloculata & -0.124 & $\mathbf{0 . 4 1 4}$ & -0.100 \\
Globotalia inflata & 0.056 & -0.028 & 0.035 \\
Globotalia truncatulinoides (L) & 0.001 & -0.001 & -0.000 \\
Globotalia truncatulinoides (R) & 0.017 & -0.007 & 0.004 \\
Globotalia crassaformis & 0.003 & -0.001 & 0.001 \\
Globotalia hirsuta & 0.003 & 0.000 & -0.001 \\
Globotalia scitula & 0.012 & -0.005 & 0.008 \\
Globotalia menardii & -0.011 & 0.044 & -0.007 \\
Globotalia tumida & 0.000 & 0.000 & -0.001 \\
Globigerinita glutinata & -0.097 & $\mathbf{0 . 7 3 1}$ & -0.202 \\
\hline Variance (\%) & 57.651 & 93.519 & 97.929 \\
Cumulative Var. (\%) & 57.651 & &
\end{tabular}

our modern western Pacific coretop database in estimating glacial downcore samples, or "non-analogue" glacial fauna assemblages existing in core MD012404.

The estimated summer SST of core MD012404 is $\sim 28.6^{\circ} \mathrm{C}$ on average during the late Holocene (Fig. $5 \mathrm{~b}$ ), and agrees well with the observed modern summer SST (NOAA 1994). This indicates the good reliability of applying RAM for estimating SST in the ECS. The LGM annual average SSTs show $\sim 1-2^{\circ} \mathrm{C}$ decreases in comparison to the late Holocene. These results are consistent with SST estimates which were based on the use of the Modern Analog Technique (MAT) on core DGKS9603 from a northern site of the ECS (Li et al. 2001). The LGM cooling shown in core MD012404 is less pronounced than that in an alkenone SST record from ODP1202 of the southern Okinawa Trough (Zhao et al. 2005). This discrepancy may be attributable to different sensitivity of faunal and alkenone changes to SST in the ECS (Chen et al. 2005). Our MD012404 SST record reveals large cooling on a millennial time scale. The annual SST decreased by $\sim 3-4^{\circ} \mathrm{C}$ during Heinrich and YD events, and appears synchronous with respect to the strengthened winter monsoon events in the stalagmite record of Hulu Cave and low temperature oscillations in the ice core record from Greenland (GISP 2) (Fig. 5c). In contrast, the SST remained stable during the PME from $\sim 3$ to 5 kya.

Although high abundances of $N$. dutertrei were reported high in surface sediments in the southern part of the Okinawa Trough and are thought to be an indicator of Kuroshio 
(a)

(b)

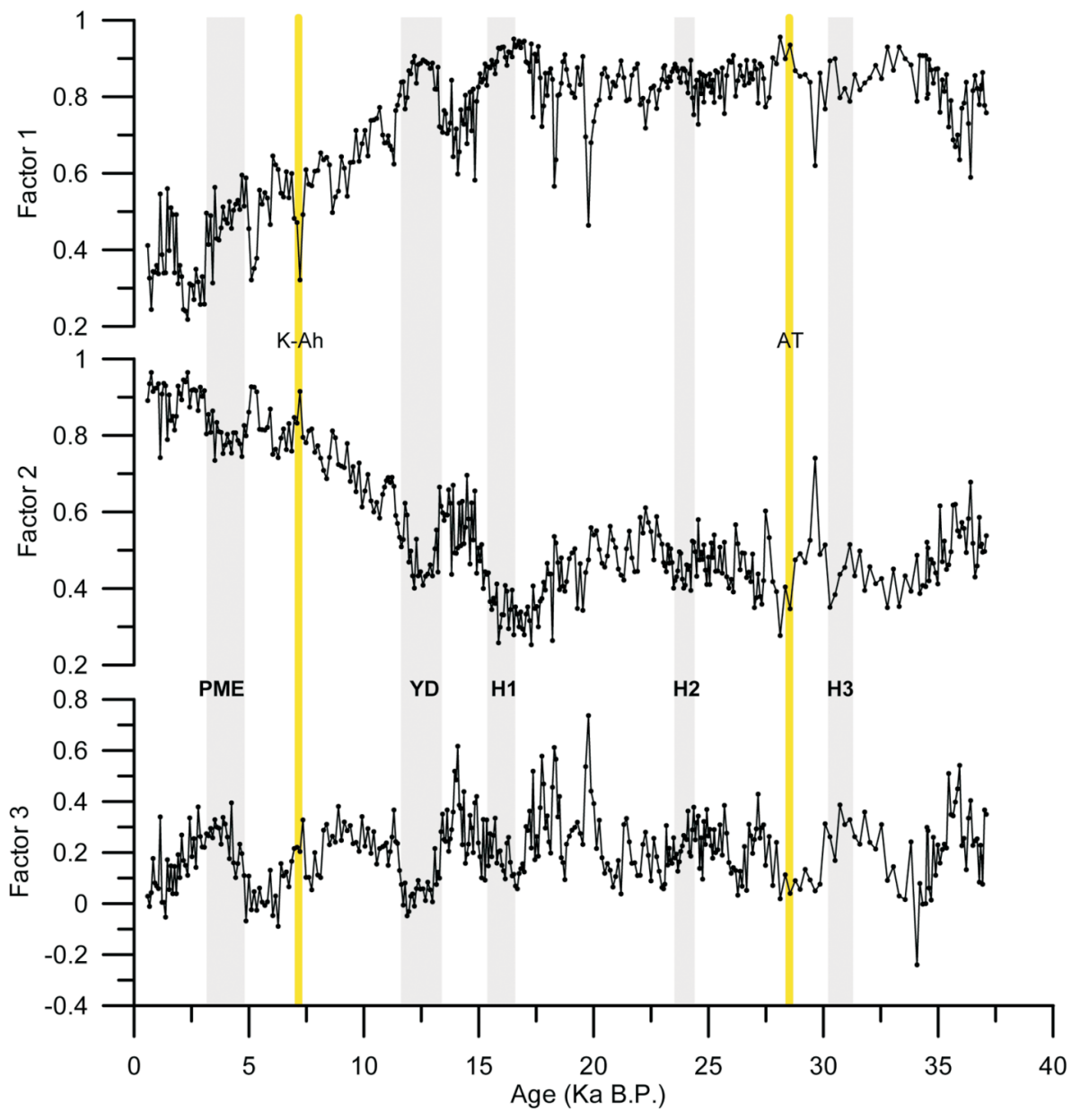

Fig. 4. Q-mode factor analysis of planktonic foraminifer fauna data. (a) Factor 1 indicates a cold water assemblage whose main contribution comes from N. dutertrei. (b) Factor 2 represents a warm water assemblage that is mainly composed of G. ruber, G. glutinata, and P. obliquiloculata. Factor 2 may indicate the influence of Kuroshio waters. (c) Factor 3 represents a coastal water assemblage whose main species is G. bulloides, an indicator of upwelling.

waters (Xu and Oda 1999; Ijiri et al. 2005), our observations in core MD012404 suggested a cold water mass control of the $N$. dutetrei distribution, since high abundances of this species occurred in the glacial stages from 40 to $16 \mathrm{kya}$. This observation is consistent with that reported by $\mathrm{Li}$ et al. (2001). In fact, our RAM SST estimates of core MD012404 were driven to relatively low values by the presence of $N$. dutertrei (Fig. 5b). This analysis indicates that $N$. dutertrei is more abundant in cold SST areas of the western Pacific. In contrast to the decline of cold water mass species, the rises of G. ruber, G. glutinata, and P. obliquiloculata abundances since $\sim 16$ kya could be attributed to the greater influence of warm water mass from the Pacific into the ECS since that time. The warm water mass appears to intrude with the Kuroshio. Rising global sea level conditions since $\sim 16$ kya, or synchronously strengthened East Asian summer monsoons, might explain the timing of the gradual warming observed in the ECS (Li et al. 1997; Kao et al. 2005).

Our observations on the abundance changes of two deep-dwelling species, G. inflata and G. truncatulinoides, help interpret surface water mixing and stratification conditions in the ECS over the past $40 \mathrm{kyr}$. Both species are considered here as preferring to live in the weakly stratified upper layers of surface oceans, which are indicative of strong East Asian winter monsoon winds. The long-term trend of decreased abundances of $G$. inflata and $G$. truncatulinoides observed in our MD012404 record may suggest a long-term weakening of the East Asian winter monsoon winds, and/or increased strength of the Kuroshio intrusion into the ECS since the glacial stages. The abundance patterns of these two deep-dwelling species in MD012404 reveal more high frequency, millennial-scale oscillations, which are indicative of the instability of winter monsoon wind strength or sea level conditions in the past 40 kyrs. In particular, our MD012404 record of G. truncatulinoides shows minima at intervals of 4 to 8 kya (Fig. 4a) and implies a short-lived, more stratified upper layer condition in surface oceans, reflecting possibly weaker East Asian winters and/ or stronger summer monsoons. An alternative explanation for this short-term event is an increase in Kuroshio water in- 
(a)

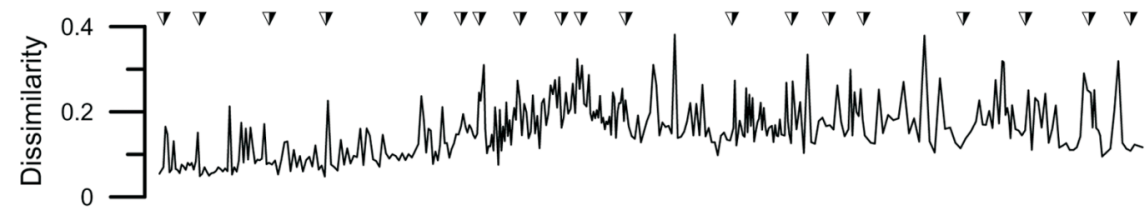

(b)

(c)

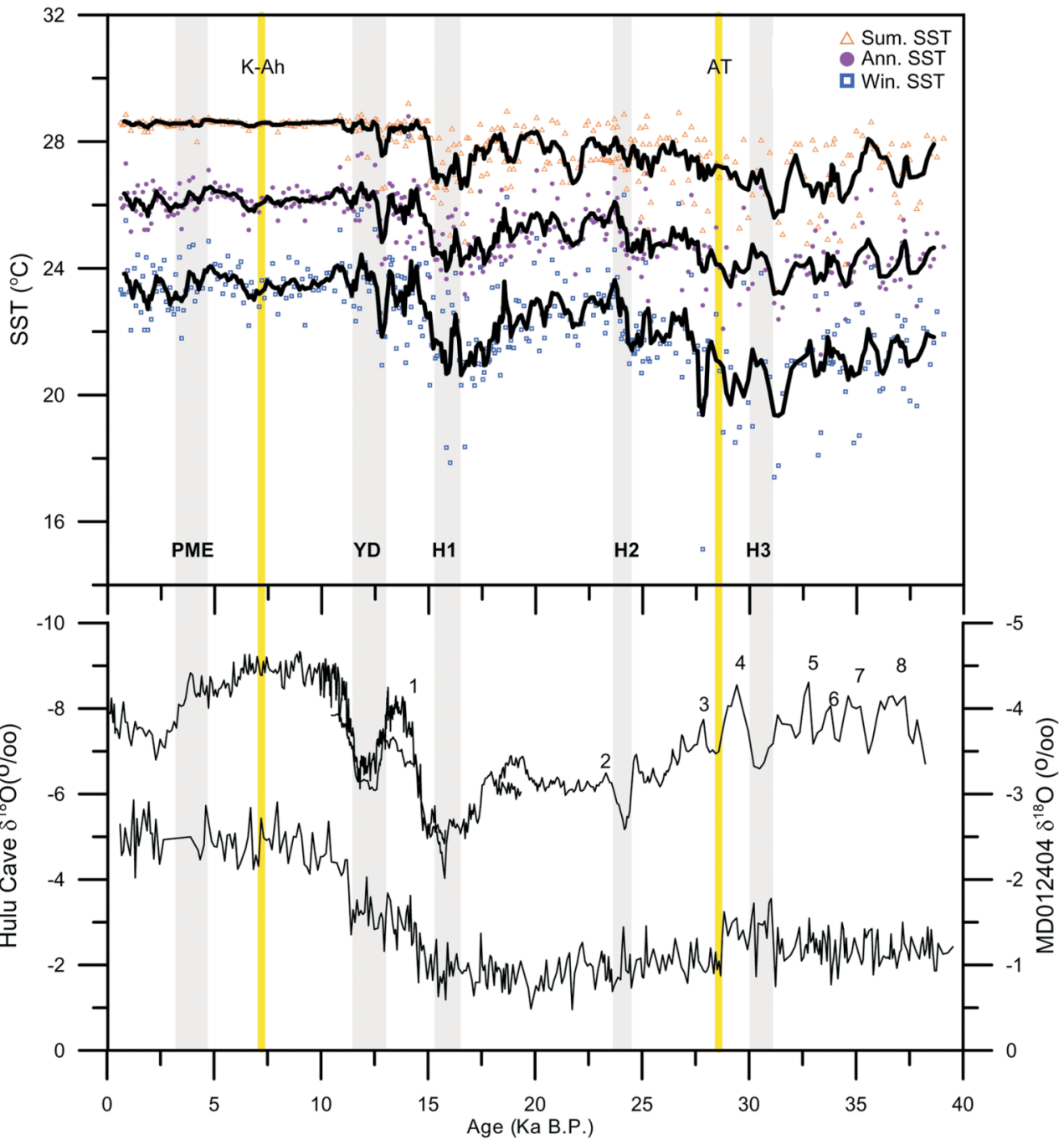

Fig. 5. Correlation between estimated RAM SST and the oxygen isotopic data from Hulu Cave. (a) Dissimilarity record; higher values mean a non-analogue situation, which is observed during glacial periods. (b) Evaluated summer (triangles), winter (squares) and annual (solid dots) SSTs of core MD012404; solid lines represent the 5 point running average values. (c) Oxygen isotopic data from Hulu Cave. Marked shadow areas represent the Heinrich events, Younger Dryas and volcanic eruptions. ${ }^{14} \mathrm{C}$ dating ages are marked with reverse triangle above.

trusion into the ECS in response to global sea level rise in the late to middle Holocene.

Low abundances of $P$. obliquiloculata in the PME have been well-documented in many previous studies and interpreted as a weak presence and/or absence of Kuroshio waters in the ECS (Li et al. 1997; Ujiié and Ujiié 1999; Jian et al. 2000b). Our RAM SST indicates no change during the PME, suggesting that this event is not responding to atmospheric or oceanic changes in the late Holocene. We speculate that the minimum abundances of $P$. obliquiloculata were not indicative of climatic changes, although a more regional comparison (Ujiié et al. 2003) of the PME suggested an El
Niño-like condition occurring in 3 to 5 kya.

Because of the high sedimentation rate and high resolution of the record, our SST shows clear LGM and also YD cooling of $\sim 1-2{ }^{\circ} \mathrm{C}$ (Fig. 5b). This temperature pattern is similar to most northern hemisphere climatic records (Bond et al. 1992; Alley et al. 1993; Alley and MacAyeal 1994), suggesting a close linkage between the ECS and high latitude climate on orbital and sub-orbital time scales. Short term cooling during the episode coincident with the YD was not reported in a recent study by Sun et al. (2005). Perhaps this may be explained by the low resolution of record A7 used in Sun et al.'s (2005) study. In addition, our studies 
identified a series of millennial-scale abrupt cooling of $\sim 3$ $4^{\circ} \mathrm{C}$ in time intervals corresponding to past Heinrich events (Fig. 5c). Moreover, our SST record mirrors the structure of the monsoon stalagmite record of Hulu Cave (Wang et al. 2001) and the ice core temperature record GISP 2 from Greenland (Fig. 5c). Low SSTs coincided with strong East Asian winter monsoons and low air temperatures over Greenland in past Heinrich and stadial cooling episodes. Although strong linkages among the climatic records are clearly indicated in terms of temperature, our MD012404 oxygen isotope variations of the planktic foraminifer $G$. ruber remain stable, particularly during intervals of Heinrich event cooling. The low SSTs should be accompanied by less saline, fresh surface water in the ECS to balance the various contributions to oxygen isotopes from temperature and salinity changes. $\mathrm{Mg} / \mathrm{Ca} \mathrm{SST}$ and planktic foraminifer oxygen isotope studies (Sun et al. 2005) have consistently suggested relatively cold and fresh conditions of millennial scale changes in the ECS. Recent studies have suggested that the ITCZ played an important role in governing temperature and precipitation patterns in the tropics on millennial scales (Peterson et al. 2000; Haug et al. 2001; Wang et al. 2001; Cruz et al. 2008). During the millennial scale cold events observed in the ECS, the ITCZ is considered here to migrate southward and to bring cold air flow from the north, which in turn decreases the SST in the ECS. We hypothesize that the southward ITCZ of millennial scale changes the focus of high precipitation to the drainage area of the Yangtze River, which supplies more river runoff and fresh water into the ECS. Alternatively, increased strength of the East Asian summer monsoon during the millennial scale cooling events could be responsible for the fresh waters in the ECS, consistent with a recent finding of high rainfall in Indonesia during cooler conditions (Visser et al. 2003).

\section{CONCLUSIONS}

We have presented high resolution planktic foraminifer fauna assemblage data and SST records from a high sedimentation rate IMAGES core retrieved from the Okinawa Trough in the ECS. The foraminifer assemblages of cold and warm water masses, and species indicative of stratified conditions in the upper layer of surface oceans, indicate an intrusion of warm water mass with less stratified surface waters since $\sim 16 \mathrm{kya}$ in the ECS. The dominance of a warm water mass since the last glacial period possibly reflects either a rising sea level or stronger East Asian summer monsoons in the interglacial periods. The fauna variations of hydrographic-sensitive species exhibit millennial scale, high frequency oscillations, indicating the instability of the Kuroshio intrusion and/or East Asian monsoon wind strength in the past 40000 years. A noticeable PME is also observed in core MD012404, consistent with many previous fauna record studies in the Okinawa Trough and the
ECS. Although the LGM and YD are characterized by relatively cold and possibly more saline surface water conditions in the ECS, our MD012404 SST record closely tracks the structure of the monsoon stalagmite record from Hulu Cave and the ice core temperature record GISP 2 from Greenland. Low SSTs and possibly low saline, fresh surface water conditions coincided with strong East Asian winter monsoons and low air temperature over Greenland in past Heinrich and stadial cooling episodes. We hypothesize that the millennial scale migrations of ITCZ in the past $40 \mathrm{kyr}$ are responsible for the SST variations observed in MD012404, and the ITCZ might change the focus of high precipitation to the drainage area of the Yangtze River during millennial scale cooling. Alternatively, East Asian summer monsoons might maintain high rainfall in the drainage area of the Yangtze River despite the cold conditions.

Acknowledgements We thank two anomalous reviewers for their comments and helpful reviews. We sincerely thank the scientists who contributed their valuable time on board in order to obtain such high-quality cores during the IMAGES 2001 WEPAMA cruise. We appreciated the contributions of the staff who work in the Core Repository and Laboratory at the National Center for Ocean Research (NCOR), which helped finish the measurements in this study. Special thanks are also due to the staff of the Earth and Planetary System Science Group, Department of Earth and Planetary Science (EPS) and Micro Analysis Laboratory, Tandem Accelerator (MALT) at The University of Tokyo, who helped us to finish the experiments of AMS- ${ }^{14} \mathrm{C}$ dating. This research was supported by the National Science Council funds (NSC95-2611-M-019-012 \& NSC95-2611-M-019-013), and the National Taiwan Ocean University, Republic of China.

\section{REFERENCES}

Ahagon, N., Y. Tanada, and H. Ujiié, 1993: Florisphaera profunda, a possible nannoplankton indicator of late quaternary changes in sea-water turbidity at the northeastern margin of the Pacific. Mar. Micropaleontol., 22, 255-273, doi: 10.1016/0377-8398(93)90047-2.

Alley, R. B. and D. R. MacAyeal, 1994: Ice-rafted debris associated with binge/purge oscillations of the Laurentide ice sheet. Paleoceanography, 9, 503-511.

Alley, R. B., D. A. Meese, C. A. Shuman, A. J. Gow, K. C. Taylor, P. M. Grootes, J. W. C. White, M. Ram, E. D. Waddington, P. A. Mayewski, and G. A. Zielinski, 1993: Abrupt increase in Greenland snow accumulation at the end of the Younger Dryas event. Nature, 362, 527-529, doi: 10.1038/362527a0.

Bard, E., F. Rostek, and G. Menot-Combes, 2004: Radiocarbon calibration beyond $20,000{ }^{14} \mathrm{C}$ yr B.P. by means of planktonic foraminifera of the Iberian Margin. Quat. Res., 61, 204-214, doi: 10.1016/j.yqres.2003.11.006. 
Bassinot, F. C., A. Baltzer, M. T. Chen, P. DeDeckker, W. Khuhnt, M. Levitan, D. Nurnberg, T. Oba, M. Prentice, M. Sarnthein, M. Situmorang, R. Tiedemann, A. Holbourn, T. Kiefer, U. Pflaumann, and S. Rothe, 2002: Scientific Report of the WEPAMA Cruise, MD122/IMAGES VII. 453.

Bé, A. W. H., 1977: An ecological, zoogeography and taxonomic review of recent planktonic foraminifera. Ocean Micropaleontol., 1, 1-100.

Beicher, R. J., 2000: Physics for Scientists and Engineers, Saunders College.

Bond, G., H. Heinrich, W. Broecker, L. D. Labeyrie, J. McManus, J. Andrews, S. Huon, R. Jantschik, S. Clasen, C. Simet, K. Tedesco, M. Klas, G. Bonani, and S. Ivy, 1992: Evidence for massive discharges of icebergs into the North Atlantic ocean during the last glacial period. Nature, 360, 245-249.

Chang, Y. P., S. M. Wu, K. Y. Wei, M. Murayama, H. Kawahata, and M. T. Chen, 2005: Foraminiferal oxygen isotope stratigraphy and high-resolution organic carbon, carbonate records from the Okinawa Trough (IMAGES MD012404 and ODP Site 1202). Terr. Atmos. Ocean. Sci., 16, 57-73.

Chen, M. T., C. C. Huang, U. Pflaumann, C. Waelbroeck, and M. Kucera, 2005: Estimating glacial western Pacific seasurface temperature: Methodological overview and data compilation of surface sediment planktic foraminifer faunas. Quat. Sci. Rev., 24, 1049-1062, doi: 10.1016/j. quascirev.2004.07.013.

Cruz, F. W., Jr, S. J. Burns, I. Karmann, W. D. Sharp, M. Vuille, A. O. Cardoso, J. A. Ferrari, P. L. Silva Dias, and O. Viana, $\mathrm{Jr}$, 2005: Insolation-driven changes in atmospheric circulation over the past 116,000 years in subtropical Brazil. $\mathrm{Na}$ ture, 434, 63-66, doi: 10.1038/nature03365.

Feldberg, M. J. and A. C. Mix, 2002: Sea-surface temperature estimates in the Southeast Pacific based on planktonic foraminiferal species; modern calibration and Last Glacial Maximum. Mar. Micropaleontol., 44, 1-29, doi: 10.1016/ S0377-8398(01)00035-4.

Grootes, P. M. and M. Stuiver, 1997: Oxygen 18/16 variability in Greenland snow and ice with $10^{-3}$-to- $10^{5}$ year time resolution. J. Geophys. Res., 102, 26455-26470.

Haug, G. H., K. A. Hughen, D. M. Sigman, L. C. Peterson, and U. Rohl, 2001: Southward migration of the Intertropical Convergence Zone through the Holocene. Science, 293, 1304-1308, doi: 10.1126/science.1059725.

Hemleben, C., M. Spindler, and O. R. Anderson, 1989: Modern Planktonic Foraminifera, Springer-Verlag, New York, 363 pp.

Hemming, S. R., 2004: Heinrich Events: Massive late Pleistocene detritus layers of the North Atlantic and their global climate imprint. Rev. Geophys., 42, 1-43.

Hsueh, Y., 2000: The Kuroshio in the East China Sea. J. Mar. Sys., 24, 131-139.

Ichikawa, H. and M. Chaen, 2000: Seasonal variation of the heat and freshwater transports by the Kuroshio in the East China Sea. J. Mar. Syst., 24, 119-129.
Ijiri, A., L. Wang, T. Oba, H. Kawahata, C. Y. Huang, and C. Y. Huang, 2005: Paleoenvironmental changes in the northern area of the East China Sea during the past 42,000 years. Palaeogeogr. Palaeoclimatol. Palaeoecol., 219, 239-261, doi: 10.1016/j.palaeo.2004.12.028.

Imbrie, J. and N. G. Kipp, 1971: A new micropaleontological method for quantitative paleoclimatology: Application to a Late Pleistocene Caribbean core. In: The Late Cenozoic Glacial Ages, New Haven, Yale University Press, 71-181.

Jian, Z., B. Li, U. Pflaumann, and P. Wang, 1996: Late Holocene cooling event in the western Pacific. Sci. Chin., 39, 543-550.

Jian, Z., B. Li, B. Huang, and J. Wang, 2000a: Globorotalia truncatulinoides as indicator of upper-ocean thermal structure during the Quaternary: Evidence from the South China Sea and Okinawa Trough. Palaeogeogr. Palaeoclimatol. Palaeoecol., 162, 287-298, doi: 10.1016/S00310182(00)00132-2.

Jian, Z., P. Wang, Y. Saito, J. Wang, U. Pflaumann, T. Oba, and $\mathrm{X}$. Cheng, 2000b: Holocene Variability of the Kuroshio Current in the Okinawa Trough, Northwestern Pacific Ocean. Earth Planet. Sci. Lett., 184, 305-319, doi: 10.1016/S0012-821X(00)00321-6.

Kao, S. J., S. C. Hsu, C. S. Horng, K. Y. Wei, and J. Chen, 2005: Enhanced deepwater circulation and shift of sedimentary organic matter oxidation pathway in the Okinawa Trough since the Holocene. Geophy. Res. Lett., 32, L15609, doi: 15610.11029/12005GL023139.

Kao, S. J., A. P. Roberts, S. C. Hsu, Y. P. Chang, W. B. Lyons, and M. T. Chen, 2006: Monsoon forcing, hydrodynamics of the Kuroshio Current, and tectonic effects on sedimentary carbon and sulfur cycling in the Okinawa Trough since 90 ka. Geophy. Res. Lett., 33, L05610, doi: 05610.01029/02005GL025154.

Kawahata, H. and H. Ohshima, 2004: Vegetation and environmental record in the northern East China Sea during the late Pleistocene. Global Planet. Change, 41, 251-273, doi: 10.1016/j.gloplacha.2004.01.011.

Kim, Y. Y., T. Qu, T. Jensen, T. Miyama, H. Mitsudera, H. W. Kang, and A. Ishida, 2004: Seasonal and interannual variations of the North Equatorial Current bifurcation in a high-resolution OGCM. J. Geophys. Res., 109, C03040, doi: 03010.01029/02003JC002013.

Klovan, J. E. and J. Imbrie, 1971: An algorithm and fortran IV program for large-scale Q-mode factor analysis and calculations of factor scores. J. Int. Assoc. Math. Geol., 3, $61-77$.

Li, B., Z. Jian, and P. Wang, 1997: Pulleniantina obliquiloculata as a Paleoceanographic indicator in the souh Okinawa Trough during the Last 20,000 Years. Mar. Micropaleontol., 32, 59-69, doi: 10.1016/S0377-8398(97) 00013-3.

Li, T., Z. Liu, M. A. Hall, S. Berne, Y. Saito, S. Cang, and Z. Cheng, 2001: Heinrich event imprints in the Okinawa Trough: Evidence from oxygen isotope and planktonic 
foraminifera. Palaeogeogr. Palaeoclimatol. Palaeoecol., 176, 133-146, doi: 10.1016/S0031-0182(01)00332-7.

Lin, Y. S., K. Y. Wei, I. T. Lin, P. S. Yu, H. W. Chiang, C. Y. Chen, C. C. Shen, H. S. Mii, and Y. G. Chen, 2006: The Holocene Pulleniatina Minimum Event revisited: Geochemical and faunal evidence from the Okinawa Trough and upper reaches of the Kuroshio current. Mar. Micropaleontol., 59, 153-170, doi: 10.1016/j.marmicro.2006. 02.003 .

Liu, Z., Y. Saito, T. Li, S. Berne, Z. Cheng, P. Li, Z. Li, F. Guichard, and G. Floch, 1999: Millennial-scale paleoceanography in the Okinawa Trough during the Late Quaternary period. Chin. Sci. Bull., 44, 1705-1709.

Machida, H., 1999: The stratigraphy, chronology and distribution of distal marker-tephras in and around Japan. Global Planet. Change, 21, 71-94.

Machida, H., 2002: Volcanoes and Tephras in the Japan Area. Global Environ. Res., 6, 19-28.

Machida, H. and F. Arai, 1976: The discovery and significance of the very widespread tephra: The Aira-Tn ash. Kagaku (Science), 46, 339-347.

Machida, H. and F. Arai, 1978: Akahoya ash - A widespread marker erupted from Kikai caldera, southern Kyushu, Japan. The Quat. Res. Jap., 17, 143-163.

National Oceanic and Atmospheric Administration (NOAA), 1994: World Ocean Atlas 1994.

Oda, M. and A. Takemoto, 1992: Planktonic foraminifera and paleoceanography in the domain of the Kuroshio Current around Japan during the last 20,000 years. Quat. Res., 31, 341-357.

Peterson, L. C., G. H. Haug, K. A. Hughen, and U. Rohl, 2000: Rapid Changes in the hydrologic cycle of the tropical atlantic during the last glacial. Science, 290, 1947-1951, doi: 10.1126/science.290.5498.1947.

Qiu, B., S. Chen, and P. Hacker, 2004: Synoptic-scale air-sea flux forcing in the Western North Pacific: Observations and their impact on SST and the mixed layer. J. Phys. Oceanogr., 34, 2148-2159.

Simmons, G. R., 1990: Subsidence history of basement sites and sites along a carbonate dissolution profile, leg 115 . Proceedings of the Ocean Drilling Program, Initial Reports, 115, 123-126.

Stuiver, M., P. J. Reimer, and R. W. Reimer, 2005: CALIB 5.0.

Sun, Y., D. W. Oppo, R. Xiang, W. Liu, and S. Gao, 2005: Last deglaciation in the Okinawa Trough: Subtropical north- west Pacific link to Northern Hemisphere and tropical climate. Paleoceanography, 20, PA4005, doi: 4010.1029/ 2004PA001061.

Sykes, T. J. S. and A. T. S. Ramsay, 1995: Calculation of mass accumulation rates in the absence of density or porosity measurements. Mar. Geol., 122, 173-179, doi: 10.1016/ 0025-3227(94)00112-X.

Thunell, R., Q. Miao, S. E. Calvert, and T. F. Pedersen, 1992: Glacial-Holocene biogenic sedimentation patterns in the South China Sea: Productivity variations and surface water $p \mathrm{CO}_{2}$. Paleoceanography, 7, 143-162.

Ujiié, H., Y. Tanaka, and T. Ono, 1991: Late Quaternary paleoceanographic record from the middle Ryukyu Trench slope, North-west Pacific. Mar. Micropaleontol., 18, 115128, doi: 10.1016/0377-8398(91)90008-T.

Ujiié, H. and Y. Ujiié, 1999: Late Quaternary course changes of the Kuroshio Current in the Ryukyu Arc region, northwestern Pacific Ocean. Mar. Micropaleontol., 37, 23-40, doi: 10.1016/S0377-8398(99)00010-9.

Ujiié, Y., H. Ujiié, A. Taira, T. Nakamura, and K. Oguri, 2003: Spatial and temporal variability of surface water in the Kuroshio source region, Pacific Ocean, over the past 21,000 years: evidence from planktonic foraminifera. Mar. Micropaleontol., 49, 335-364, doi: 10.1016/S0377-8398 (03)00062-8.

Visser, K., R. Thunell, and L. Stott, 2003: Magnitude and timing of temperature change in the Indo-Pacific warm pool during deglaciation. Nature, 421, 152-154, doi: 10.1038/ nature 01297.

Waelbroeck, C., L. Labeyrie, J. C. Duplessy, J. Guiot, M. Labracherie, M. Leclair, and J. Duprat, 1998: Improving past sea surface temperature estimates based on planktonic fossil faunas. Paleoceanography, 13, 272-283.

Wang, Y. J., H. Cheng, R. L. Edwards, Z. S. An, J. Y. Wu, C. C. Shen, and J. A. Dorale, 2001: A High-resolution absolute-dated late Pleistocene monsoon record from Hulu Cave, China. Science, 294, 2345-2348, doi: 10.1126/ science. 1064618.

Xu, X. and M. Oda, 1999: Surface-water evolution of the eastern East China Sea during the last 36,000 years. Mar. Geol., 156, 285-304, doi: 10.1016/S0025-3227(98) 00183-2.

Zhao, M., C. Y. Huang, and K. Y. Wei, 2005: A 28,000 year $\mathrm{U}_{37}^{\mathrm{k}^{\prime}}$ sea surface temperature record of ODP Site 1202B, Southern Okinawa Trough. Terr. Atmos. Ocean. Sci., 16, 45-56. 